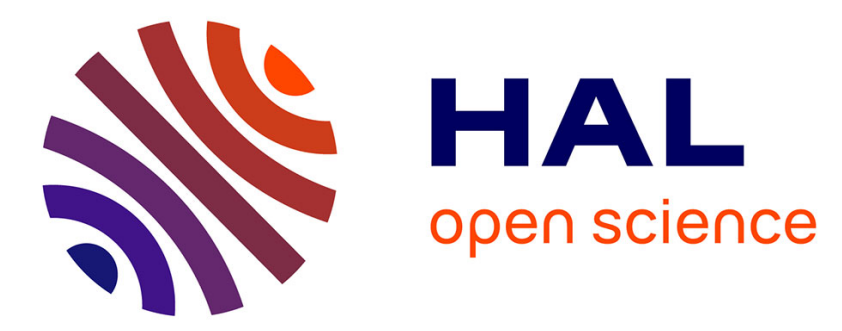

\title{
A 25-year record of polycyclic aromatic hydrocarbons in soils amended with sewage sludges
}

\author{
Eric Lichtfouse, V. Sappin-Didier, L. Denaix, G. Caria, L. Metzger, N.
}

Amellal-Nassr, Julien Schmidt

\section{- To cite this version:}

Eric Lichtfouse, V. Sappin-Didier, L. Denaix, G. Caria, L. Metzger, et al.. A 25-year record of polycyclic aromatic hydrocarbons in soils amended with sewage sludges. Environmental Chemistry Letters, 2005, 3 (3), pp.140-144. 10.1007/s10311-005-0010-5 . hal-00174156

\author{
HAL Id: hal-00174156 \\ https://hal.science/hal-00174156
}

Submitted on 24 Sep 2007

HAL is a multi-disciplinary open access archive for the deposit and dissemination of scientific research documents, whether they are published or not. The documents may come from teaching and research institutions in France or abroad, or from public or private research centers.
L'archive ouverte pluridisciplinaire HAL, est destinée au dépôt et à la diffusion de documents scientifiques de niveau recherche, publiés ou non, émanant des établissements d'enseignement et de recherche français ou étrangers, des laboratoires publics ou privés. 


\section{Eric Lichtfouse*, Valérie Sappin-Didier, Laurence Denaix, Giovanni Caria, Laure Metzger, Najat Amellal-Nassr, Jens Schmidt \\ A 25-year record of polycyclic aromatic hydrocarbons in soils amended with sewage sludges}

\begin{abstract}
10.1007/s00410-002-0431-0
We studied polycyclic aromatic hydrocarbons (PAHs) in crop soils amended with 1,000 tons dry weight of sewage sludges per 10,000 $\mathrm{m}^{2}$ from 1974 to 1992 , then after sludges addition from 1993 to 1999. The absence of variations of total PAHs levels of control soils, averaging at $123 \mu \mathrm{g} / \mathrm{Kg}$, shows the absence of horizontal contamination. During sludges addition the total PAHs levels in amended soils increased from 232 to $402 \mu \mathrm{g} / \mathrm{Kg}$. Seven years after sludges addition, it decreased to $275 \mu \mathrm{g} / \mathrm{Kg}$, which is still more than twice higher than levels of control soils. This finding shows that sludges PAHs are preserved in crop soils for long periods of time, on a human scale.
\end{abstract}

Keywords soil, PAH, sewage sludge, maize, crop, pollutant

\section{Introduction}

Polycyclic aromatic hydrocarbons (PAHs) are a class of organic compounds widely occurring in various media such as soils, sediments, waters, aerosols, food and living organisms (Lichtfouse et al. 2005). PAHs are of environmental concern because some PAHs such as benzo[a]pyrene have shown mutagenic and carcinogenic properties. Light aromatic hydrocarbons occurring in contaminated soils and tars inhibit the growth of plants (Henner et al. 1999). Some PAHs such as phenanthrene and benzo[a]pyrene can easily be transferred through the food chain to end in blood (Laurent et al. 2001). Nonetheless, in many instances, it is difficult to assess the precise origin of PAHs, e.g. natural versus anthropogenic as discussed by Lichtfouse et al (1997). It is even more difficult to make a clear relationship between PAH contact to living organisms and the later occurrence of an illness such as cancer.

On earth, PAHs are produced either rapidly during

Eric Lichtfouse*, Valérie Sappin-Didier ${ }^{1}$, Laurence Denaix ${ }^{2}$, Giovanni Caria $^{3}$, Laure Metzger ${ }^{4}$, Najat Amellal-Nassr ${ }^{4}$, Jens Schmidt ${ }^{5}$

*Corresponding author. INRA-CMSE, 17, rue Sully, 21000 Dijon, France.

${ }^{2}$ INRA Bordeaux, ${ }^{3}$ INRA Arras, France. ${ }^{4}$ Rittmo, France. ${ }^{5}$ Environment

\& Resources DTU, Denmark

Eric.Lichtfouse@epoisses.inra.fr
Accepted: $₫ \oplus \uparrow /$ Published online: $₫ \oplus \uparrow$

C Springer-Verlag 2005

combustion processes, e.g. vegetation fires and vehicle exhausts, or slowly during the maturation of organic matter in sediments. They usually occur in minute amounts in most natural media, with exceptions such as petroleum pools, organic-rich sediments and soils after vegetation fires. On the other hand, PAHs are usually concentrated in locations of high human activity, e.g. near major highways, in major cities and in some industrial soils (Henner et al. 1997, Bryselbout et al. 2000).

PAHs are concentrated in sewage sludges. Urban sewage sludges are very complex media inherited from the decay of animal, vegetal and rain wastes. Huge quantities of sewage sludges are produced, amounting yearly to about 850,000 tons dry weight in France and 7.7 million tons in Europe in 1998. There are two main options for the treatment of sewage sludges. Firstly, incineration is fast but costly and leads to a rapid input of the greenhouse gas carbon dioxyde in the atmosphere. Secondly, recycling in crop soils is convenient because sewage sludges are excellent fertilisers as they are rich in NPK elements (Sommers, 1977). Moreover, this process should be more sustainable that incineration regarding carbon dioxyde emissions, as a part of sludge carbon should stay in the soil for some time. Nonetheless sewage sludges contain pollutants that could be further transferred to the food chain and ground waters (Wilson et al. 1996).

The knowledge on the fate of PAHs in soils amended with sewage sludges in scarce, notably in the long term (Wilson et al. 1997). Here we report PAH levels in experimental maize crop soils during sludges addition (1974-1992) and after sludges addition (1993-1999). Crop soils have been amended with high loads of sewage sludges, amounting to 1,000 tons dry weight of sewage sludges per $10,000 \mathrm{~m}^{2}$ from 1974 to 1992 . 


\section{Experimental}

\section{Samples}

The INRA experimental crop field "Ambarès" in Bordeaux, France, is splitted into 25 plots including plots amended with sewage-sludges and non-amended plots. The $0-20 \mathrm{~cm}$ sandy soils studied here have been sampled from two plots: a plot amended with 100 tons sewage sludges dry weight per hectare (ha: $10,000 \mathrm{~m}^{2}$ ) each 2 years from 1974 to 1992 (total 1,000 tons); and a non-amended plot (control). Soils have been sampled during sludge addition from 1974 to 1992, and after sludge addition from 1993-1999. The following samples were analysed: 1) sludge-amended soils from years 1976, 1978, 1979, 1981, 1986, 1989, 1993, 1997, 1999; 2) non-amended soils (control plots) from years 1976 , 1989, 1999; and 3) a sewage sludges sample from 1991. Noteworthy, the non-amended plot is located near a sewage sludges amended plot to check for possible cross contamination. All plots were cropped with maize during and after sewage sludges addition. Samples were dried, 2 mm-sieved and stored at $20^{\circ} \mathrm{C}$.

\section{PAH analysis}

Detailed procedures will be reported elsewhere. Briefly, dried soil samples were finely ground, then a 5-20 g subsample (2 $\mathrm{g}$ for dried sludges) was extracted by accelerated solvent extraction (ASE) at 103.4 bar first at $100^{\circ} \mathrm{C}$ with acetone-methylene chloride $50 / 50 \mathrm{v} / \mathrm{v}$ then at $150^{\circ} \mathrm{C}$ with acetone-hexane $50 / 50 \mathrm{v} / \mathrm{v}$. Extracts were mixed, concentrated in vacuo to about $0.5 \mathrm{~mL}$ then to dryness under a gentle nitrogen flow.

Extracts were analysed by high performance liquid chromatography (HPLC)-fluorimetry. Conditions: autosampler, $20 \mu \mathrm{l}$ injector loop, $100 \times 4.6$ ed Hypersil PAH column $\left(5 \mu \mathrm{m}\right.$ phase), oven temperature $40^{\circ} \mathrm{C}$. Elution with water/acetonitrile $(\mathrm{v} / \mathrm{v}): 50 / 505 \mathrm{~min}$ isocratic, then $50 / 50$ to $0 / 100$ in $20 \mathrm{~min}$. Wavelength detector program $(\mathrm{nm}$ exitation, $\mathrm{nm}$ emission): 0-7.8 $\mathrm{min}(226,322), 7.8-15 \mathrm{~min}$ (268, 462), 15-18.10 (234, 420), 18.10-21.5 (268, 398), 21.5-25 (302, 500). Two fluorimetric detectors are coupled in series to avoid peak overlapping. The first detector is used for naphthalene, acenaphthene, fluorene, fluoranthene, benzo[b]fluoranthène, benzo[a]pyrene and indeno[123cd]pyrene. The second detector is used for phenanthrene, anthracene, pyrene, benzo[a]anthracene, chrysene, benzo[k]fluoranthene, dibenzo[ah]anthracene and benzo[ghi]pyrene.

Linear calibration was done using standard PAHs solutions at 40,100, 200,400,600,800,1000 $\mu \mathrm{g} / \mathrm{L}$, and gave a regression coefficient higher than 0.99. Before each series a methanol extraction blank, a $600 \mu \mathrm{g} / \mathrm{L}$ PAHs standard solution, and a sewage sludge standard are injected to control quality. The methanol blank was considered valid below $100 \mu \mathrm{g} / \mathrm{L}$ total PAHs $(46 \mu \mathrm{g} / \mathrm{L}$ are usually found). The analytical deviation of the $600 \mu \mathrm{g} / 1$ PAHs standard solution averaged at $\pm 2.5 \%$ for fluoranthene $(604 \pm 15 \mu \mathrm{g} / \mathrm{L})$ and extended from $\pm 8 \mu \mathrm{g} / \mathrm{L}(1.3 \%)$ to \pm 43 $\mu \mathrm{g} / \mathrm{L}(7.1 \%)$, for 86 runs over 26 weeks. The analytical deviation of the sewage sludge standard averaged at $\pm 5.5 \%$ for fluoranthene $(1.26 \pm 0.07 \mathrm{mg} / \mathrm{Kg})$ and extended from \pm $0.02 \mathrm{mg} / \mathrm{Kg}(1.5 \%)$ to $\pm 0.14 \mathrm{mg} / \mathrm{Kg}(11.1 \%)$, for $59 \mathrm{runs}$ over 26 weeks.

\section{Results and discussion}

\section{Background}

Maize crop soils have been amended with 100 tons sewage sludges dry weight (d.w.) per hectare each 2 years from 1974 to 1992 amounting to a total of 1,000 tons, and then further cropped with maize until 1999. Noteworthy, the quantity of added sludge was well above the current French policy of January $8^{\text {th }} 1998$ that limits the addition to 30 tons d.w. per ha over 10 years. The concentrations of PAHs in amended soils, control soils and sewage sludges are reported in table 1. In sewage sludges, the concentration in $\mu \mathrm{g} / \mathrm{Kg}$ of fluoranthene (906), benzo[b]fluoranthene (292) and benzo[a]pyrene (166) are well below the French policy levels of 5000, 2500 and $2000 \mu \mathrm{g} / \mathrm{Kg}$, respectively.

\section{PAH distributions}

The distributions of polycyclic aromatic hydrocarbons in soils and sludges are presented in figure 1. In sewage sludges the distribution shows a predominance of light PAHs such as fluorene and phenanthrene. All control soils show the predominance of benzo[ghi]perylene. By comparison, there is a dominance of lighter PAHs in amended soils during sludges addition, which is consistent with an input of PAHs from sewage sludges. Then, seven years after the last sludges addition (1992), the amended soils (1999) show a reverse trend with the dominance of heavy PAHs such as benzo[k]fluoranthene and benzo[ghi]perylene. This trend is again consistent with the end of sewage sludges addition. The distribution of PAHs in amended soils is therefore consistent with the mixing of PAHs from control soils and from sewage sludges. The main possible effects ruling the fate in PAH in soils are preservation, degradation, volatilisation and formation of bound-residues.

Figure 1. Distribution of polycyclic aromatic hydrocarbons in sewage sludges (1991), a control soil (1976), an amended soil during sludges addition (1989), and an amended soil 7 years after sludges addition. Note that the distribution of PAHs in amended soils is consistent with a mixing of PAHs from control soils and sewage sludges. Note also that 7 years after the last sludges addition, the distribution of the amended soil do not match that of the control soil, suggesting that sludges PAHs are preserved in soil. Ace: acenaphthene, Flu: fluorene, Phe: phenanthrene, Flt: fluoranthene, Pyr: pyrene, BbF: benzo[b]fluoranthene, BkF: benzo[k]fluoranthene, BaP: benzo[a]pyrene, Bpe: benzo[ghi]perylene, Ind: indeno[1,2,3-cd]pyrene.

Two major observations should be noted. First, even seven years after the end of sludges addition, the $\mathrm{PAH}$ distributions of amended soils do not match the distribution of control soils. This result suggests that a part of PAHs 
from sludges are remaining in the soil, despite 7 years of maize cropping and weather exposition. Second, benzo[k]fluoranthene shows an unexpected behaviour because its dominance in amended soils 7 years after sludges addition cannot be explained considering its low relative concentration in sewage sludges and in control soils.

To conclude, the PAH distributions of amended soils are consistent with the mixing of PAHs from control soils and sewage sludges. The behaviour of benzo[k]fluoranthene is unexpected. Furthermore, even 7 years after the last sludges addition, PAH distributions do not match those of control soils. Those points will be further discussed in the next sections showing in detail the time changes of $\mathrm{PAH}$ concentrations in soils.

\section{PAH concentration in soils}

The time trends of total PAHs, phenanthrene, benzo[a]pyrene and benzo[k]fluoranthene in sludgesamended soils and in control soils from 1974 to 1999 are drawn on Figure 2. The double-sided arrow shows the time period of sludges addition (1974-1992). The results show that control soils dot not show any increase of PAH levels of $105-134 \mu \mathrm{g} / \mathrm{Kg}$ averaging at $123 \mu \mathrm{g} / \mathrm{Kg}$, despite the location of control plots within a frame of other plots that were heavily amended with sewage sludges. This finding gives evidence for the absence of significant horizontal contamination from amended plots.

Figure 2. Concentration of polycyclic aromatic hydrocarbons (PAHs) in sludges amended soils and control soils. Note the absence of variation of PAHs levels in control soils. Note that PAHs levels increase during sludges addition, then decrease except for benzo[k]fluoranthene. Note that 7 years after sludges addition, the total PAHs level of the amended soil is still more than twice higher than that of the control soil.

Further, the start of sludges addition in 1974 leads to a strong increase of total PAHs levels in soils from 134 $\mu \mathrm{g} / \mathrm{Kg}$ for the control soil to $232 \mu \mathrm{g} / \mathrm{Kg}$ for the sludgesamended soil (1976). During sludges addition, from 1974 to 1992, the levels of total PAHs in amended soils increase from 232 to $402 \mu \mathrm{g} / \mathrm{Kg}$, and then decrease after sludges addition. Nonetheless, 7 years after the last sludges addition (1999), the total PAHs levels in soils still amounts to $275 \mu \mathrm{g} / \mathrm{Kg}$, which is more than twice the content of control soils $(105-134 \mu \mathrm{g} / \mathrm{Kg})$. This finding is rather unexpected because several factors should have favoured the degradation and washing of PAHs: the permeable structure of sandy soils, the cropping with maize and a temperate climate with regular raining. PAHs are therefore somehow preserved in the soil for long periods of time. Such process of preservation of organic compounds in soils has been previously evidenced for PAHs and $n$-alkanes using isotope analysis (Lichtfouse et al., 1997, 1998). To conclude, the total PAH level is still twice higher than background 7 years after the last sludges addition, despite conditions that should have favoured their degradation and washing.
Concerning the behaviour of specific soil PAHs, during sludges addition (1974-1992), all PAHs show levels that are much higher than levels control soils, except for benzo[ghi]perylene (Table 1). During sludges addition, from 1974 to 1992, all PAHs show increasing levels, except for benzo[ghi]perylene (Table 1, figure 2). After sludge addition (1993-1999), most PAHs levels decrease more or less steadily, but do not go back to control levels, except for fluorene and benzo[ghi]perylene. On the other hand, benzo[k]fluoranthene show increasing levels after sludges addition (Fig. 2). Here this behaviour suggests an external source of benzo[k]fluoranthene.

\section{Conclusion}

The distribution of PAHs in soils amended with sewage sludges is consistent with the mixing of sewages sludges and control soils. During sludges addition, from 1974 to 1992, the level of total PAHs in soils increases from 232 to $307 \mu \mathrm{g} / \mathrm{Kg}$, and then decreases after sludges addition. Nonetheless, 7 years after the last sludges addition (1999), the total PAHs levels in soils still amounts to $275 \mu \mathrm{g} / \mathrm{Kg}$, which is more than twice the content of control soils (105$134 \mu \mathrm{g} / \mathrm{Kg}$ ). A part of sludges PAHs are therefore well preserved in soils for long period of time, on a human scale.

\section{Acknowledgements}

This work has been supported by the European Commission under the fifth framework programme and contributing to the implementation of the key action "Sustainable Management and Quality of Water", project Biowaste QLK5-CT-200201138, and the Institut National de la Recherche Agronomique.

\section{References}

Bryselbout C, Henner P, Carsignol J, Lichtfouse E. (2000) Polycyclic aromatic hydrocarbons in highway plants and soils. Evidence for a local distillation effect. Analusis 28:290-293

Henner P, Schiavon M, Morel JL, Lichtfouse E. (1997) Polycyclic aromatic hydrocarbon (PAH) occurrence and remediation methods. Analusis Mag 25: M56-M59

Henner P, Schiavon M, Druelle V, Lichtfouse E (1999) Phytotoxicity of ancient gaswork soils. Effect of polycyclic aromatic hydrocarbons (PAHs) on plant germination. Org Geochem 30: 963-969

Laurent C, Feidt C, Lichtfouse E, Grova N, Laurent F, Rychen G (2001) Milk-blood transfer of ${ }^{14} \mathrm{C}$-tagged polycyclic aromatic hydrocarbons (PAHs) in pigs. J Agric Food Chem 49: 2493-2496 
Lichtfouse E, Budzinski H, Garrigues P, Eglinton TI (1997)

Ancient polycyclic aromatic hydrocarbons in modern soils:

${ }^{13} \mathrm{C},{ }^{14} \mathrm{C}$ and biomarker evidence. Org Geochem 26: 353-359

Lichtfouse E, Wehrung P, Albrecht P (1998) Plant wax $n$-alkanes trapped in soil humin by noncovalent bonds. Naturwissenschaft 85:449452

Lichtfouse E, Schwarzbauer J, Robert D (2005) (Eds) Part IV. Polycyclic aromatic hydrocarbons. In: Environmental Chemistry. Springer, Berlin, pp 393-459

Sommers LE (1977) Chemical composition of sewage sludges and analysis of their potential use as fertilizers. J Environmental Qual 6: 225-232

Wilson SC, Alcock RE, Sewart AP, Jones KC (1997) Persistence of organic contaminants in sewage sludgeamended soil: a field experiment. J Environ Qual 26: 14671477

Wilson SC, Duarte-Davidson R, Jones KC (1996) Screening the environmental fate of organic contaminants in sewage sludges applied to agricultural soils : 1 . The potential for downward movement to groundwaters. Sci Tot Environ $18545-57$ 
Table 1. Concentration in $\mu \mathrm{g} / \mathrm{Kg}$ dry weight of polycyclic aromatic hydrocarbons (PAHs) in soils amended with sewage sludges, soils from control plots, and sewage sludges. Years refers to sampling years. Ace: acenaphthene, Flu: fluorene, Phe: phenanthrene, Flt: fluoranthene, Pyr: pyrene, BbF: benzo[b]fluoranthene, BkF: benzo[k]fluoranthene, BaP: benzo[a]pyrene, Bpe: benzo[ghi]perylene, Ind: indeno[1,2,3-cd]pyrene

\begin{tabular}{|c|c|c|c|c|c|c|c|c|c|c|c|}
\hline Year & Ace & Flu & Phe & Flt & Pyr & $\mathrm{BbF}$ & $\mathrm{BkF}$ & $\mathrm{BaP}$ & Bpe & Ind & Total \\
\hline \multicolumn{12}{|c|}{ Soils amended with sewage sludges } \\
\hline 1976 & 3 & 6 & 41 & 21 & 24 & 27 & 15 & 15 & 55 & 25 & 232 \\
\hline 1978 & 3 & 8 & 86 & 45 & 44 & 36 & 20 & 21 & 62 & 32 & 357 \\
\hline 1979 & 3 & 6 & 71 & 35 & 38 & 25 & 16 & 14 & 41 & 26 & 275 \\
\hline 1981 & 4 & 6 & 71 & 35 & 26 & 25 & 16 & 14 & 41 & 26 & 264 \\
\hline 1986 & 4 & 4 & 57 & 30 & 28 & 30 & 20 & 17 & $<40$ & 29 & 259 \\
\hline 1989 & 7 & 6 & 109 & 50 & 47 & 44 & 23 & 26 & 54 & 36 & 402 \\
\hline 1993 & 6 & 4 & 58 & 35 & 31 & 35 & 40 & 18 & 50 & 30 & 307 \\
\hline 1997 & 5 & 2 & 35 & 43 & 35 & 37 & 41 & 27 & 46 & 35 & 306 \\
\hline 1999 & 5 & 2 & 35 & 34 & 31 & 34 & 45 & 18 & 44 & 27 & 275 \\
\hline \multicolumn{12}{|c|}{ Soils non-amended with sewage sludges (control plots) } \\
\hline 1976 & $<1$ & 3 & 31 & 17 & 11 & 11 & 5 & 5 & $<40$ & 10 & 134 \\
\hline 1989 & $<1$ & 3 & 27 & 16 & 11 & 11 & 5 & 6 & $<40$ & 10 & 130 \\
\hline 1999 & $<1$ & 3 & 14 & 12 & 9 & 8 & 4 & 5 & $<40$ & 9 & 105 \\
\hline \multicolumn{12}{|c|}{ Sewage sludges } \\
\hline 1991 & $<51$ & 1350 & 906 & 617 & 667 & 292 & 199 & 166 & $<527$ & $<267$ & 5043 \\
\hline
\end{tabular}




\section{FIGURE 1}

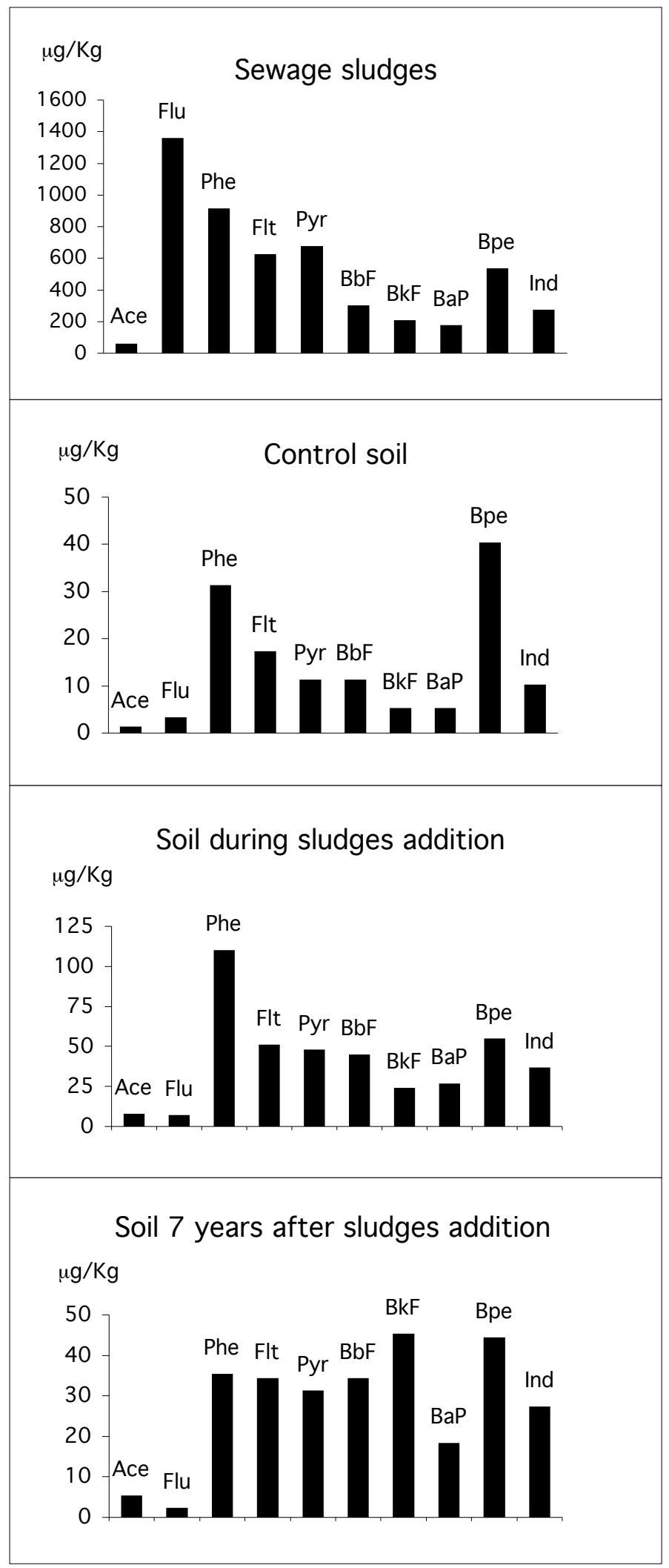

Figure 1. Distribution of polycyclic aromatic hydrocarbons in sewage sludges (1991), a control soil (1976), an amended soil during sludges addition (1989), and an amended soil 7 years after sludges addition. Note that the distribution of PAHs in amended soils is consistent with a mixing of PAHs from control soils and sewage sludges. Note also that 7 years after the last slugdes addition, the distribution of the amended soil do not match that of the control soil, suggesting that slugdes PAHs are preserved in soil. Ace: acenaphthene, Flu: fluorene, Phe: phenanthrene, Flt: fluoranthene, Pyr: pyrene, BbF: benzo[b]fluoranthene, BkF: benzo[k]fluoranthene, BaP: benzo[a]pyrene, Bpe: benzo[ghi]perylene, Ind: indeno[1,2,3-cd]pyrene. 


\section{FIGURE 2}

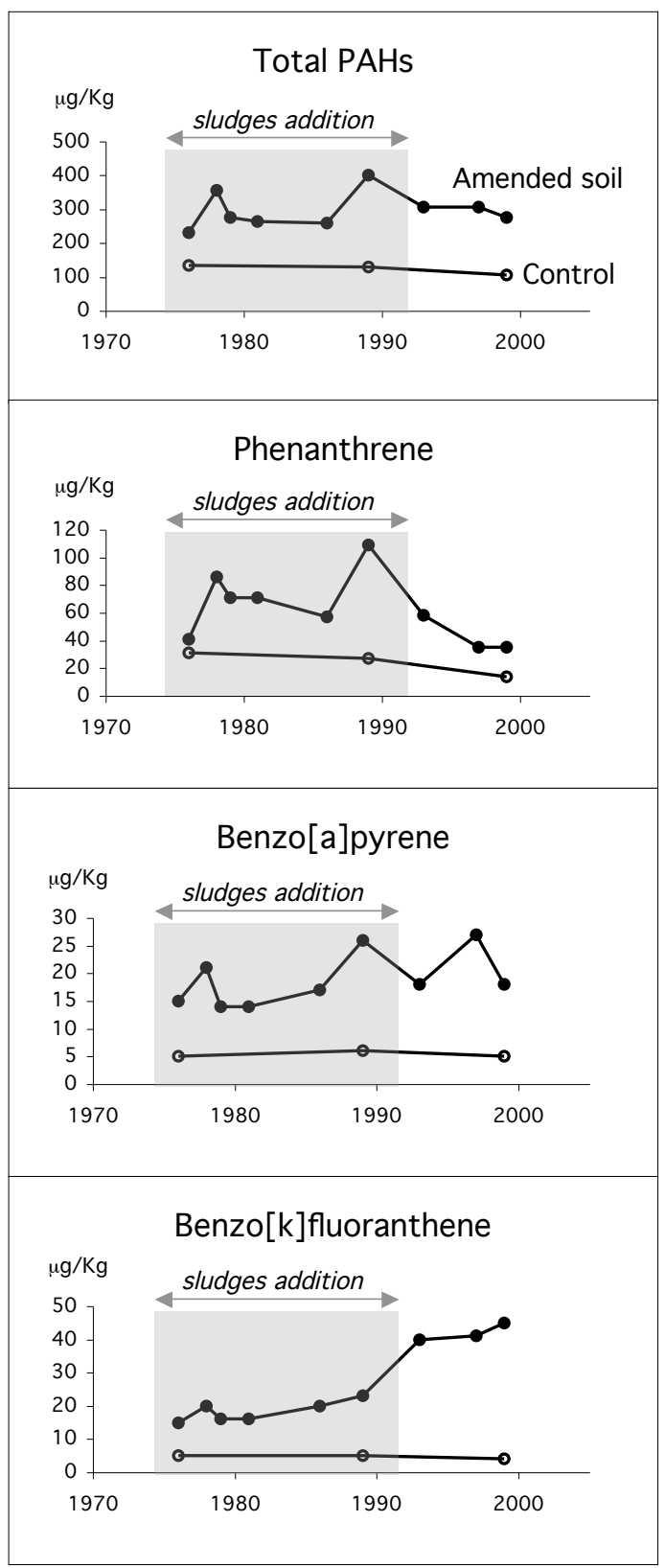

Figure 2. Concentration of polycyclic aromatic hydrocarbons (PAHs) in sludges amended soils and control soils. Note the absence of variation of PAHs levels in control soils. Note that PAHs levels increase during sludges addition, then decrease except for benzo[k]fluoranthene. Note that 7 years after sludges addition, the total PAHs level of the amended soil is still more than twice higher than that of the control soil. 